\title{
Surface Thermal Insulation and Pipe Cooling of Spillways during Concrete Construction Period
}

\author{
Wang Zhenhong, ${ }^{1}$ Liu Yi, ${ }^{1}$ and Yu Shuping ${ }^{2}$ \\ ${ }^{1}$ Department of Structures and Materials, China Institute of Water Resources and Hydropower Research, Beijing 100038, China \\ ${ }^{2}$ Henan Yellow River Reconnaissance, Design and Research Institute, Beijing Branch, Beijing 100073, China \\ Correspondence should be addressed to Wang Zhenhong; faithzhen@126.com
}

Received 7 March 2014; Revised 7 June 2014; Accepted 7 June 2014; Published 7 July 2014

Academic Editor: Cheng Shao

Copyright (c) 2014 Wang Zhenhong et al. This is an open access article distributed under the Creative Commons Attribution License, which permits unrestricted use, distribution, and reproduction in any medium, provided the original work is properly cited.

Given that spillways adopt a hydraulic thin concrete plate structure, this structure is difficult to protect from cracks. The mechanism of the cracks in spillways shows that temperature stress is the major reason for cracks. Therefore, an effective way of preventing cracks is a timely and reasonable temperature-control program. Studies show that one effective prevention method is surface thermal insulation combined with internal pipe cooling. The major factors influencing temperature control effects are the time of performing thermal insulation and the ways of internal pipe cooling. To solve this problem, a spillway is taken as an example and a three-dimensional finite element program and pipe cooling calculation method are adopted to conduct simulation calculation and analysis on the temperature fields and stress fields of concretes subject to different temperature-control programs. The temperature-control effects are then compared. Optimization results show that timely and reasonable surface thermal insulation and water-flowing mode can ensure good temperature-control and anticrack effects. The method has reference value for similar projects.

\section{Introduction}

With the increasing investment of China on their water conservancy projects, water resources of the southwest part have been gradually developed. Many major water conservancy projects have thus been established, including dams, spillways, and spillway tunnels, as well as other large-scale structures. As a consequence, the crack problem is subject to growing concern. High flow rate, large capacity, and high intensity of water put forward extremely high requirements for the comprehensive performances, construction technologies, and appearance quality of these concrete structures. Generally, spillways use high-grade impact and abrasion resistant concrete characterized by high cement content, high adiabatic temperature rise, quick temperature rise at early stage, and early strengthening. In addition, the spillways have thin floors, long partings along the rivers, and high basic constraint. These characteristics determine that temperature control is the key to ensuring project quality $[1-8]$.
With the existing temperature control measures, cracks are difficult to avoid in impact and abrasion resistant concrete [9-17]. Therefore, conducting monographic study on the temperature-control program of concrete construction under high grade is necessary. High adiabatic temperature rise and high restraint conditions are also needed to determine the risk of cracking in the construction scheme and to propose reasonable and an effective temperature-control program. Engineering practice shows that surface thermal insulation and internal pipe cooling are the main methods to reduce this kind of cracks [18-22]. Surface thermal insulation can help reduce the temperature difference between the interior and exterior of the structure and reduce the impact of sudden ambient temperature change. Although this measure is a major one for preventing early cracks, it increases the temperature of the concrete to the highest level, the cooling rate at a later stage, and concrete shrinkage. The internal pipe cooling of the concrete can take away the heat generated by concrete so as to prevent excessive temperature increase, 
as well as to reduce the temperature difference between the interior and exterior of the structure and the cooling rate. However, internal pipe cooling requires reasonable and proper water-flowing duration, water temperature, and flow rate $[6,22]$. In view of this problem, this paper adopts a threedimensional finite element program to calculate and analyze the temperature-control effects of different combinations of surface thermal insulation and water cooling methods based on one of the large-scale domestic spillways. Comparative analysis has been made and a reasonable temperature-control and crack-resistant program has been selected to guide the on-site construction.

\section{Calculation Principles and Methods}

2.1. Basic Theory of Unstable Temperature Field and Finite Element Method (FEM). At any point within the computational domain $R$, the unstable temperature field $T(x, y, z, t)$ must conform to the heat conduction equation [6]:

$$
\frac{\partial T}{\partial t}=a\left(\frac{\partial^{2} T}{\partial x^{2}}+\frac{\partial^{2} T}{\partial y^{2}}+\frac{\partial^{2} T}{\partial z^{2}}\right)+\frac{\partial \theta}{\partial \tau},
$$

where $T$ is temperature $\left({ }^{\circ} \mathrm{C}\right), a$ is the temperature conductivity coefficient $\left(\mathrm{m}^{2} \cdot \mathrm{h}^{-1}\right), \theta$ is the adiabatic temperature rise of the concrete $\left({ }^{\circ} \mathrm{C}\right), t$ is time (day), and $\tau$ is age (day).

By adopting the variation principle, formula (1) is subject to spatial discretisation and time-domain difference. After the introduction of the initial and boundary conditions, the recursive formula for calculating the temperature field finite element of the backward difference becomes available:

$$
\left([H]+\frac{1}{\Delta t_{n}}[R]\right)\left\{T_{n+1}\right\}-\frac{1}{\Delta t_{n}}[R]\left\{T_{n}\right\}+\left\{F_{n+1}\right\}=0,
$$

where $[H]$ is the thermal conductivity matrix, $[R]$ is the complementary thermal conductivity matrix, $\left\{T_{n}\right\}$ and $\left\{T_{n+1}\right\}$ are the junction temperature arrays, $\left\{F_{n+1}\right\}$ is the junction temperature load array, $n$ is the period ordinal, and $\Delta t$ is the time step. According to the recurrence formula (2), the junction temperature of the next moment $\left\{T_{n+1}\right\}$ can be calculated based on the junction temperature of the previous moment $\left\{T_{n}\right\}$.

2.2. Principles and Methods for Calculating the Temperature Field of the Concrete Subject to Water Cooling. The water temperature increments along the pipe can be calculated according to the Fourier law of heat conduction and the thermal equilibrium conditions [6]:

$$
\Delta T_{w i}=\frac{-\lambda}{c_{w} \rho_{w} q_{w}} \iint_{\Gamma^{0}} \frac{\partial T}{\partial n} d s,
$$

where $q_{w}, c_{w}$, and $\rho_{w}$ are the flow rate, specific heat, and density of the cooling water, respectively; $\lambda$ is the thermal conductivity coefficient and $n$ is the outer normal of the concrete surface between the concrete and pipe.

2.3. Basic Theory of Stress Field and the FEM. The strain increments of concrete under complex stress conditions include elastic strain increment, creep strain increment, temperature strain increment, drying shrinkage strain increment, and autogenous volume strain increment [6]. Therefore,

$$
\left\{\Delta \varepsilon_{n}\right\}=\left\{\Delta \varepsilon_{n}^{e}\right\}+\left\{\Delta \varepsilon_{n}^{c}\right\}+\left\{\Delta \varepsilon_{n}^{T}\right\}+\left\{\Delta \varepsilon_{n}^{s}\right\}+\left\{\Delta \varepsilon_{n}^{0}\right\},
$$

where $\left\{\Delta \varepsilon_{n}^{e}\right\}$ is the elastic strain increment, $\left\{\Delta \varepsilon_{n}^{c}\right\}$ is the creep strain increment, $\left\{\Delta \varepsilon_{n}^{T}\right\}$ is the temperature strain increment, $\left\{\Delta \varepsilon_{n}^{s}\right\}$ is the drying shrinkage strain increment, and $\left\{\Delta \varepsilon_{n}^{0}\right\}$ is the autogenous volume strain increment.

The FEM governing equation for the area $R_{i}$ at any time duration $\Delta t_{i}$ can be calculated according to the relevant physical, geometric, and equilibrium equations:

$$
\left[K_{i}\right]\{\Delta \delta\}_{i}=\left\{\Delta P_{i}^{G}\right\}+\left\{\Delta P_{i}^{C}\right\}+\left\{\Delta P_{i}^{T}\right\}+\left\{\Delta P_{i}^{S}\right\}+\left\{\Delta P_{i}^{0}\right\},
$$

where $\left\{\Delta \delta_{i}\right\}$ is the displacement increment of all the nodes within the area $R_{i}$ at three directions and $\left\{\Delta P_{i}^{G}\right\},\left\{\Delta P_{i}^{C}\right\}$, $\left\{\Delta P_{i}^{T}\right\},\left\{\Delta P_{i}^{S}\right\}$, and $\left\{\Delta P_{i}^{0}\right\}$ are the equivalent nodal force increments during $\Delta t_{i}$ period caused by external load, creep, variable temperature, drying shrinkage, and autogenous volume deformation, respectively.

\section{Causes and Mechanism of Cracks in the Spillway during a Concrete-Construction Period}

3.1. Causes with respect to Materials. The special functions and features of spillways confirm that high-performance concrete with good strength, impact, and abrasion resistance is often used. However, high-performance concrete has various thermal properties such as small water-cement ratio, high cement content, high hydration heat, high adiabatic temperature rise, and an adiabatic temperature rise mainly concentrated at the early stage. It also has some mechanical properties such as large elasticity modulus, early strengthening, and large autogenous volume deformation. These properties make cracks difficult to control and become common and hard to prevent.

3.2. Causes with respect to Structure. Unlike the concrete structure of a dam, spillways have thin structures with a thickness of 1-2 m. Unlike the aqueduct structure, spillways have very simple structures, without the deformation constraint between the floor and flank wall, side wall and floor, and main beam and floor. Unlike dams and aqueducts, spillways often have long partings along the river, and the entire structure of a spillway is under a strongly restrained zone. The structure is also subject to obvious restrain of the foundation, so cracks are easily generated. Once a crack appears, it is usually a penetrating crack that greatly affects the durability and security of the spillway structure.

In short, the characteristics of spillways with respect to material and structure confirm that they are sensitive to cracks. Spillways have more stringent anticrack requirements, and cracking is difficult to prevent. Minimizing harmful cracks during construction is of great importance for the future security of a project. 


\section{Surface Thermal Insulation and Pipe Cooling Calculation of Spillways during a Concrete-Construction Period}

4.1. Project Overview. The hydropower station is located at the lower reach of Lantsang River at the junction of Simao District of Puer City and Lancang County, Yunan Province. It is at the fifth cascade in the eight-cascade planning for the middle-lower reach of Lantsang River. The open spillway of the hydropower station is arranged on the left bank of the dam and consists of the intake channel section, lock chamber section, chute section, deflecting bucket section, and the stilling pond section at the outlet. The spillway has an overall horizontal length of $1445.183 \mathrm{~m}$, a width of $151.5 \mathrm{~m}$, and a thickness of about $1 \mathrm{~m}$. This spillway is China's largest and the world's second largest with the largest discharge power. This spillway adopts $\mathrm{C}_{180} 55 \mathrm{~W} 8 \mathrm{~F} 100$ grade-II concrete. It is subject to year-round construction, and the temperature-control and crack-resistant tasks are complex and arduous. The concrete mix ratio is shown in Table 1, and the relevant thermal and mechanical parameters are shown in Table 2.

4.2. Calculation Model. When calculating the temperature field, the bottom and the four sides of the foundation are taken as the adiabatic boundaries and the four sides and the top of the spillway are taken as category- 3 boundary conditions. The ambient temperature adopts the average temperature over years. An equivalent algorithm is adopted for calculation once water cooling starts [6]. For stress field calculation, the bottom of the foundation is regarded as the fixed and the four sides are supported by connecting rods; other boundary surfaces are all regarded as free-form deformation surfaces. The temperature and stress gradients are large because the areas near the four sides and the top of the spillway are subject to the impact of ambient temperature. Meanwhile, the temperature and stress changes of the surface concrete are also key points for temperature-control and anticrack studies. Therefore, relatively thin elements will be set and the grids become gradually enlarged from the exterior to the interior. The smallest element thickness is $0.01 \mathrm{~m}$, whereas the largest element thickness is $0.1 \mathrm{~m}$. A spatial hexahedron isoparametric element model is used when conducting meshing. The elements and node numbers of the calculation model are 41544 and 46615 , respectively. The computational grid is shown in Figure 1 (part of the foundation grid is shown).

4.3. Temperature-Control and Anticracking Program. The spillway uses high-performance concrete and is subject to year-round construction. Given the limited space, only a section of the spillway concrete constructed in summer is taken as an example to explain the temperature-control methods, such as surface thermal insulation and internal water pipe cooling. To achieve optimum temperature-control results, multiparameter and multicombination numerical simulation calculations are carried out. Temperature-control solutions in different combinations are shown in Table 3.

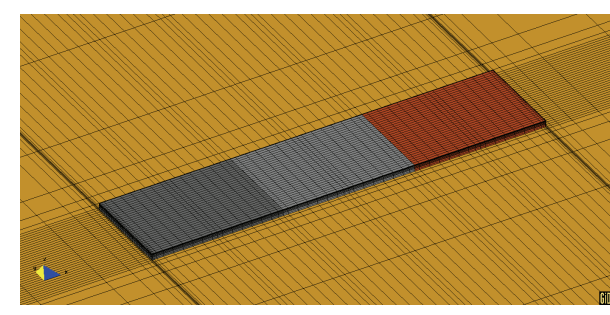

FIGURE 1: Simulation calculation grid.

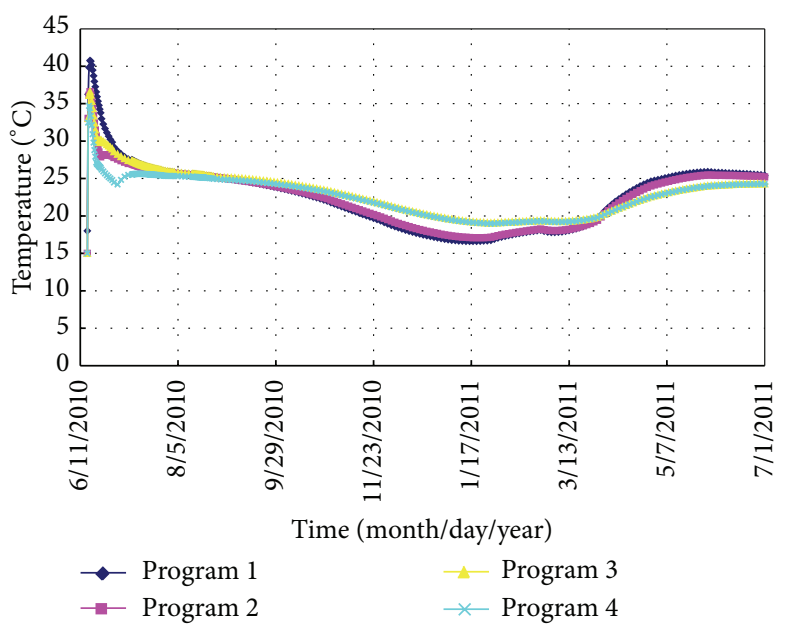

FIGURE 2: Thermograms of internal temperatures for various programs.

The above programs are sequentially set; the next program is proposed based on the calculation results of the previous program and according to the problems existing in the construction conditions and the calculation results. Therefore, it is a gradual optimization process as a whole and the ultimate purpose is to provide the optimal temperaturecontrol program.

4.4. Analysis of Calculated Results. The results of simulation calculation are shown in Table 4 and Figures 2, 3, 4, and 5. According to the comparative analysis of the typical point temperature and stress change process of concrete under different programs, the following observations are made.

(1) To understand the variation laws of temperature and stress, Program 1 is set to be the construction condition with no temperature-control measure. The calculation results show that the maximum temperature inside the spillway concrete can reach $41.75^{\circ} \mathrm{C}$ without any temperature-control measure. Without surface thermal insulation, the temperature decreases to $31.12^{\circ} \mathrm{C}$ on day 9 , with a decreasing amplitude of $9.54^{\circ} \mathrm{C}$ and a cooling rate of $1.1^{\circ} \mathrm{C} \cdot \mathrm{day}^{-1}$. Considering that the construction is carried out on a hot weather, the concrete temperature changes with the ambient temperature; it continuously decreases and reaches the minimum value in the middle of next January. 


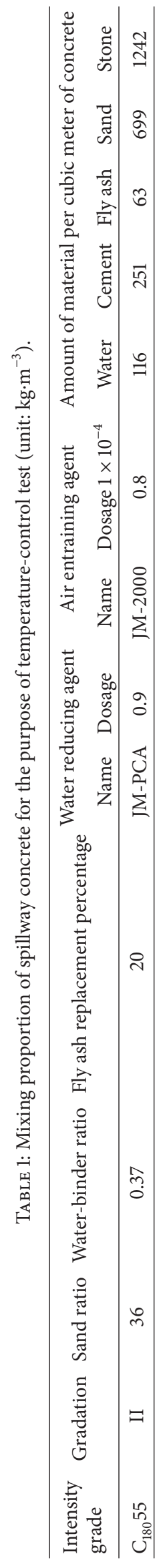


TABLE 2: Thermal and mechanical parameters of spillway concrete.

\begin{tabular}{|c|c|c|c|c|c|c|c|c|}
\hline \multirow{2}{*}{$\begin{array}{l}\text { Intensity } \\
\text { grade }\end{array}$} & \multirow{2}{*}{$\begin{array}{c}\text { Thermal conductivity } \\
\text { coefficient }\left[\mathrm{kJ} \cdot\left(\mathrm{m} \cdot \mathrm{h} \cdot{ }^{\circ} \mathrm{C}\right)^{-1}\right]\end{array}$} & \multirow{2}{*}{$\begin{array}{l}\text { Specific heat } \\
{\left[\mathrm{kJ} \cdot\left(\mathrm{kg} \cdot{ }^{\circ} \mathrm{C}\right)^{-1}\right]}\end{array}$} & \multirow{2}{*}{$\begin{array}{l}\text { Linear expansion } \\
\text { coefficient }\left[\left({ }^{\circ} \mathrm{C}\right)^{-1}\right]\end{array}$} & \multirow{2}{*}{$\begin{array}{c}\text { Adiabatic } \\
\text { temperature rise }\left[{ }^{\circ} \mathrm{C}\right]\end{array}$} & \multirow{2}{*}{ Poisson's ratio } & \multicolumn{3}{|c|}{ Elastic modulus [GPa] } \\
\hline & & & & & & 7 days & 28 days & 90 days \\
\hline $\mathrm{C}_{180}$ & 9.83 & 0.985 & $8.3 \times 10^{-6}$ & $\begin{array}{c}48.67 \times t \times(0.61+ \\
t)^{-1}\end{array}$ & 0.167 & 32.4 & 33.9 & 37.5 \\
\hline
\end{tabular}

TABLE 3: Temperature-control program.

\begin{tabular}{|c|c|c|c|c|c|c|}
\hline \multirow[b]{2}{*}{ Program } & \multirow[b]{2}{*}{$\begin{array}{l}\text { Pouring } \\
\text { temperature }\left[{ }^{\circ} \mathrm{C}\right]\end{array}$} & \multirow[b]{2}{*}{$\begin{array}{l}\text { Surface thermal insulation } \\
{\left[\mathrm{kJ} \cdot\left(\mathrm{m}^{2} \cdot \mathrm{h} \cdot{ }^{\circ} \mathrm{C}\right)^{-1}\right]}\end{array}$} & \multirow[b]{2}{*}{$\begin{array}{l}\text { Target } \\
\text { temperature }\left[{ }^{\circ} \mathrm{C}\right]\end{array}$} & \multicolumn{3}{|c|}{ Water pipe cooling } \\
\hline & & & & $\begin{array}{l}\text { Spacing } \\
{[\mathrm{m} \times \mathrm{m}]}\end{array}$ & Water & $\begin{array}{l}\text { Flow rate } \\
{\left[\mathrm{m}^{3} \cdot \mathrm{h}^{-1}\right]}\end{array}$ \\
\hline Program 1 & 15 & - & - & $1.0 \times 1.0$ & - & - \\
\hline Program 2 & 15 & 20 & 28 & $1.0 \times 1.0$ & 13 & 2.0 \\
\hline Program 3 & 15 & $\begin{array}{l}\text { The thermal insulation coefficient is } 20 \text { at } \\
\text { early stage and } 5 \text { after October. }\end{array}$ & 28 & $1.0 \times 1.0$ & 13 & 2.0 \\
\hline Program 4 & 15 & $\begin{array}{l}\text { Curing with flowing water is conducted at } \\
\text { the early stage and the thermal insulation } \\
\text { coefficient is } 5 \text { after October. }\end{array}$ & 28 & $1.0 \times 1.0$ & 13 & 2.0 \\
\hline
\end{tabular}

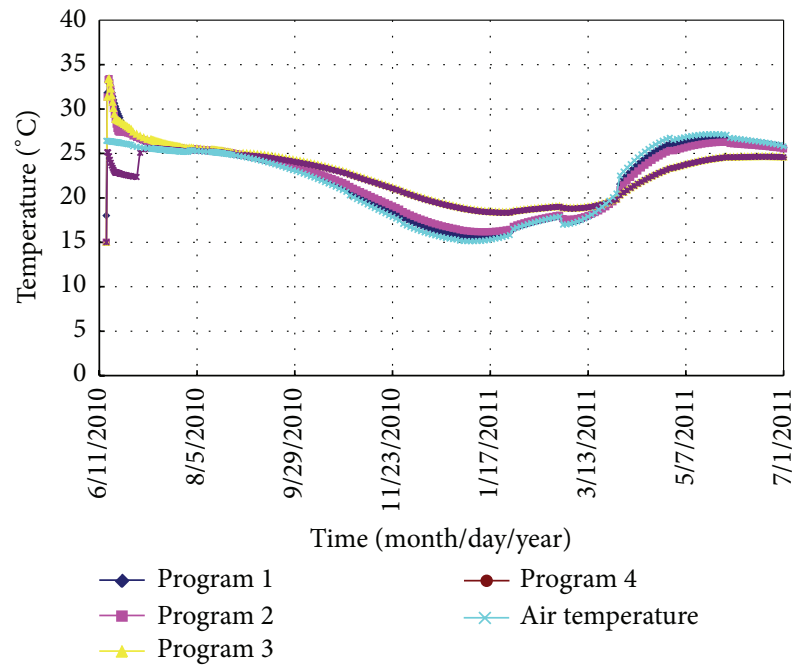

FIgURE 3: Thermograms of surface temperatures for various programs.

The concrete temperature decreases from its maximum temperature of $41.75^{\circ} \mathrm{C}$ to its minimum temperature of $16.62^{\circ} \mathrm{C}$, with the decreasing amplitude above $25^{\circ} \mathrm{C}$. Given that the structure is thin walled and is under a strong constraint condition, stress continuously increases and reaches its maximum value of $3.89 \mathrm{MPa}$ at the age of 207 days (next January), exceeding the allowable tension stress of concrete and with a safety factor of only 1.15 .

(2) Program 2 adopts temperature control measures on the basis of Program 1. The temperature-control measure is found to result in the following: surface thermal insulation coefficient of $20 \mathrm{~kJ} \cdot\left(\mathrm{m}^{2} \cdot \mathrm{h} \cdot{ }^{\circ} \mathrm{C}\right)^{-1}$, water temperature of $13^{\circ} \mathrm{C}$, flow rate of $2.0 \mathrm{~m}^{3} \cdot \mathrm{h}$, and

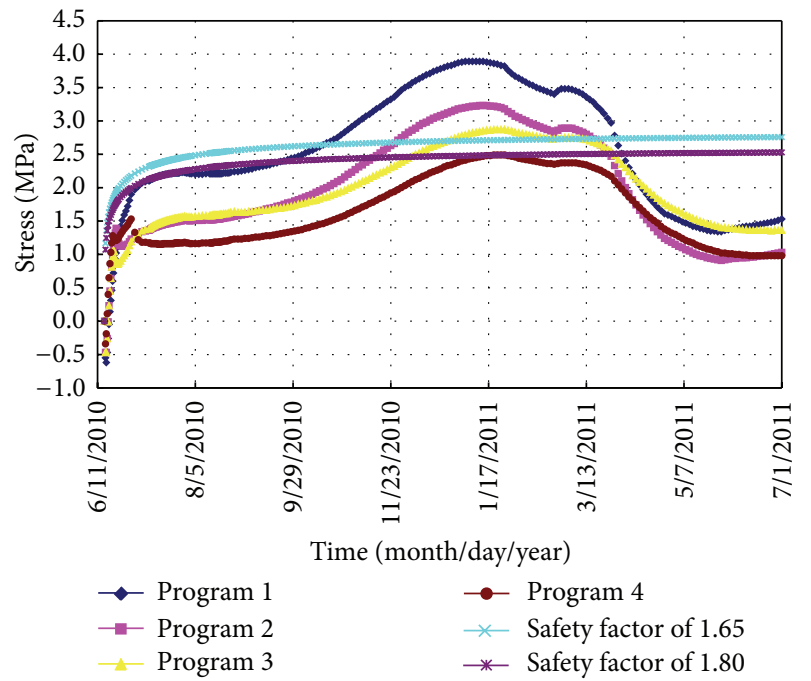

FIGURE 4: Internal stress hydrograph of various programs.

target temperature of $28^{\circ} \mathrm{C}$. Under these conditions, the maximum temperature of the concrete decreases from $41.75^{\circ} \mathrm{C}$ to $37.19^{\circ} \mathrm{C}$. Considering surface thermal insulation, the temperature decreasing amplitude and the cooling rate of the concrete decrease. However, the maximum stress still exists in the next January when the air temperature is the lowest. The maximum along-the-flow stress of the concrete is $3.25 \mathrm{MPa}$ and the safety factor of the concrete is only about 1.37. The improvement of stress is very limited.

(3) Program 3 adopts a different surface thermal insulation measure. In particular, the initial thermal insulation coefficient is $20 \mathrm{~kJ} \cdot\left(\mathrm{m}^{2} \cdot \mathrm{h} \cdot{ }^{\circ} \mathrm{C}\right)^{-1}$. When the air temperature begins to significantly decrease (from 
TABLE 4: Highest temperature and maximum stress of the spillway cast according to different programs in summer.

\begin{tabular}{|c|c|c|c|c|c|c|c|}
\hline \multirow{2}{*}{ Program } & \multicolumn{4}{|c|}{ Inside the concrete } & \multicolumn{3}{|c|}{ Surface of the concrete } \\
\hline & $\begin{array}{c}\text { Highest } \\
\text { temperature }\left[{ }^{\circ} \mathrm{C}\right]\end{array}$ & $\begin{array}{c}\text { Maximum along-the-flow } \\
\text { stress [MPa] }\end{array}$ & $\begin{array}{l}\text { Age } \\
\text { [day] }\end{array}$ & $\begin{array}{l}\text { Safety } \\
\text { factor }\end{array}$ & $\begin{array}{c}\text { Maximum along-the-flow } \\
\text { stress }[\mathrm{MPa}]\end{array}$ & $\begin{array}{l}\text { Age } \\
{[\text { day }]}\end{array}$ & $\begin{array}{l}\text { Safety } \\
\text { factor }\end{array}$ \\
\hline Program 1 & 41.75 & 3.89 & 207 & 1.15 & 3.37 & 201 & 1.33 \\
\hline Program 2 & 37.19 & 3.25 & 213 & 1.37 & 3.18 & 205 & 1.40 \\
\hline Program 3 & 37.60 & 2.87 & 225 & 1.56 & 2.73 & 219 & 1.64 \\
\hline Program 4 & 35.42 & 2.50 & 225 & 1.79 & 1.77 & 215 & 2.53 \\
\hline
\end{tabular}

October), $5 \mathrm{~kJ} \cdot\left(\mathrm{m}^{2} \cdot \mathrm{h} \cdot{ }^{\circ} \mathrm{C}\right)^{-1}$ insulation materials are used. Calculation results show that this measure can greatly reduce the stress of the concrete. However, the safety factor is still about 1.6.

(4) Program 4 is proposed based on the above temperature-control measures. In Program 4, flowing water is used to further reduce the maximum temperature of the concrete at the early stage. When the air temperature significantly decreases (from October), the concrete is covered with thermal insulation material whose thermal insulation coefficient is $5 \mathrm{~kJ} \cdot\left(\mathrm{m}^{2} \cdot \mathrm{h} \cdot{ }^{\circ} \mathrm{C}\right)^{-1}$ so as to reduce the impact of air temperature on the concrete. Calculation results show that, due to the water curing adopted at the early stage, the maximum temperature of the concrete decreases to about $35.7^{\circ} \mathrm{C}$, the decreasing amplitude is obvious, and the initial safety factor is above 2.0. The maximum stress starts in the next January. The maximum stress of the concrete is only about $2.50 \mathrm{MPa}$ because the thermal insulation material whose thermal insulation coefficient is $5 \mathrm{~kJ} \cdot\left(\mathrm{m}^{2} \cdot \mathrm{h} \cdot{ }^{\circ} \mathrm{C}\right)^{-1}$ is used after October to significantly decrease the temperature fluctuation amplitude of the concrete. The safety factor is about 1.80 and the safety factor on the surface of the concrete is above 2.50 .

According to the results of the above multimode and multiparameter calculation and analysis, the recommended temperature control measures for pouring the impact and abrasion resistant spillway concrete in summertime are as follows: (1) the pouring temperature will not exceed $15^{\circ} \mathrm{C}$; (2) water curing will be adopted for the concrete surface at the early stage; (3) the temperature of the flowing water is about $22^{\circ} \mathrm{C}$; (4) the curing time is 18 days; (5) the cooling water temperature is controlled at $13^{\circ} \mathrm{C}$ or below before the temperature peak; (6) after the temperature peak, gradually decreasing the flow rate and increasing the water temperature are necessary; (7) the maximum daily cooling rate within 5 days after the temperature peak will not exceed $1^{\circ} \mathrm{C}$; $(8)$ the maximum cooling rate will not exceed $0.5^{\circ} \mathrm{C}$ after 5 days; (9) cooling is stopped when the concrete reaches $28^{\circ} \mathrm{C}$ and then natural cooling is resumed to a stable temperature; (10) from October, the poured spillway concrete surface is covered with materials whose thermal insulation coefficient is $5 \mathrm{~kJ} \cdot\left(\mathrm{m}^{2} \cdot \mathrm{h} \cdot{ }^{\circ} \mathrm{C}\right)^{-1}$.

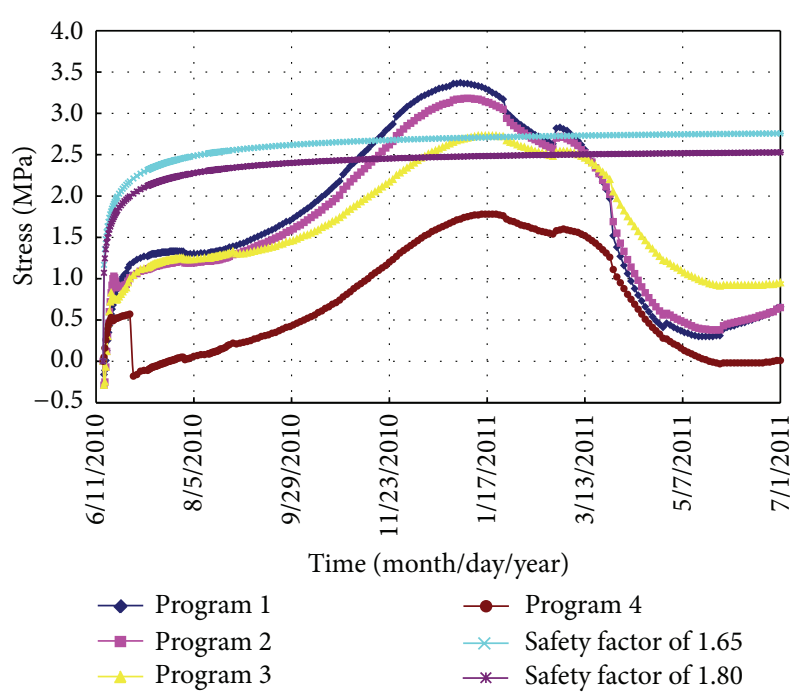

FIGURE 5: Surface stress hydrograph of various programs.

\section{Conclusion}

The results of this work indicate the following.

(1) Spillways generally use high-grade impact and abrasion resistant concrete characterized by high cement content, high adiabatic temperature rise, quick temperature rise at early stage, and early strengthening. Spillways also have thin floors, long partings along the rivers, and high basic constraint. The structural characteristics of high-grade concrete determine temperature control and crack prevention which are more difficult to carry out during the construction period of a spillway.

(2) Surface thermal insulation and internal pipe cooling are the main methods of reducing this kind of cracks. Surface thermal insulation can help reduce the temperature difference between the interior and exterior of the structure, the impact of sudden ambient temperature change on the structure, and the temperature fluctuation of concrete, and this method is a major crack-prevention measure. Water cooling can prevent the concrete temperature from excessively increasing and can reduce the rate of temperature rise 
and temperature difference between the interior and exterior of the concrete. Combination of both has better temperature-control and crack-prevention effects. However, the thermal insulation coefficient and the cooling method will be reasonable and proper.

(3) Different temperature control measures have different temperature-control and crack-prevention effects. Each measure is required to be reasonable and proper; otherwise, no good temperature-control and crackprevention effect can be achieved; sometimes, even adverse effect may be generated. Therefore, multiparameter and multimode simulation calculation and analysis are necessary to carry out to select suitable temperature-control and crack-prevention programs.

\section{Conflict of Interests}

The authors declare that there is no conflict of interests regarding the publication of this paper.

\section{Acknowledgments}

The authors acknowledge the support provided by the National Natural Science Foundation of China (Grant no. 51209235), the Governmental Public Industry Research Special Funds for Projects (Grant no. 201201050), the 973 Project (nos. 2013CB036406 and 2013CB035904), the Special Scientific Fund sponsored by IWHR for Department of Structures and Materials (nos. 1309, 1353, 1361, and 1169), and the Twelfth Five-Year Science and Technology Project (SQ2013BAJY4138B02).

\section{References}

[1] A. K. Schindler, B.S.E., M.S.E. Concrete Hydration, Temperature Development, and Setting at Early-Ages, The University of Texas at Austin, 2002.

[2] C. D. Atiş, "Heat evolution of high-volume fly ash concrete," Cement and Concrete Research, vol. 32, no. 5, pp. 751-756, 2002.

[3] A. K. Schindler, B. F. McCullough, and T. S. Krauss, "The design of a high performance concrete pavement in the Waco District, Texas," Research Report 0215-1F, The Center for Transportation Research, The University of Texas at Austin, 1999.

[4] V. G. Papadakis, "Effect of fly ash on Portland cement systems. Part II. High-calcium fly ash," Cement and Concrete Research, vol. 30, no. 10, pp. 1647-1654, 2000.

[5] S. Tsimas and A. Moutsatsou-Tsima, "High-calcium fly ash as the fourth constituent in concrete: problems, solutions and perspectives," Cement \& Concrete Composites, vol. 27, no. 2, pp. 231-237, 2005.

[6] B.-F. Zhu, Thermal Stresses and Temperature Control of Mass Concrete, China Electric Power Press, Beijing, China, 1998.

[7] M. S. Konsta-Gdoutos and S. P. Shah, "Hydration and properties of novel blended cements based on cement kiln dust and blast furnace slag," Cement and Concrete Research, vol. 33, no. 8, pp. 1269-1276, 2003.

[8] R. C. Tank and N. J. Carino, "Rate constant functions for strength development of concrete," ACI Materials Journal, vol. 88, no. 1, pp. 74-83, 1991.
[9] B. Sioulas and J. G. Sanjayan, "Hydration temperatures in large high-strength concrete columns incorporating slag," Cement and Concrete Research, vol. 30, no. 11, pp. 1791-1799, 2000.

[10] S. P. Senadheera and D. G. Zollinger, "Influence of coarse aggregate in Portland Cement Concrete on spalling of concrete pavements," Research Report 1244-11, Texas Transportation Institute, College Station, Texas, Tex, USA, 1994.

[11] M. I. Sánchez de Rojas and M. Frías, “The pozzolanic activity of different materials, its influence on the hydration heat in mortars," Cement and Concrete Research, vol. 26, no. 2, pp. 203213, 1996.

[12] Z. P. Bazant and W. P. Murphy, "Creep and shrinkage prediction model for analysis and design of concrete structures-model $\mathrm{B}_{3}$," Materiaux et Constructions, vol. 28, no. 180, pp. 357-365, 1995.

[13] H. Zanni, M. Cheyrezy, V. Maret, S. Philippot, and P. Nieto, "Investigation of hydration and pozzolanic reaction in reactive powder concrete (RPC) using 29Si NMR," Cement and Concrete Research, vol. 26, no. 1, pp. 93-100, 1996.

[14] L. J. Parrot, "Factors influencing relative humidity in concrete," Magazine of Concrete Research, vol. 43, no. 154, 1991.

[15] M. J. Shannag and A. Yeginobali, "Properties of pastes, mortars and concretes containing natural pozzolan," Cement and Concrete Research, vol. 25, no. 3, pp. 647-657, 1995.

[16] B. F. McCullough and R. O. Rasmussen, "Fast-track paving: concrete temperature control and traffic opening criteria for bonding concrete overlays, volume 1," Final Report FHWA-RD98-167, U.S Department of Transportation, Washington, DC, USA, 1999.

[17] Z. Wang, G. Zhang, and Y. Liu, "Study on the application of cooling pipe in thin-walled concrete structure," Advanced Materials Research, vol. 163-167, pp. 1107-1110, 2011.

[18] Z.-M. Zhang, X.-W. Guo, and R.-Q. Du, "Analysis of hydration heat-induced stresses and cracks in massive concrete walls," Journal of Hohai University, vol. 30, no. 5, pp. 12-16, 2002.

[19] D. Lelièvre, V. Nicolas, and P. Glouannec, "Numerical modelling of heat and mass transfer in porous materials during drying and shrinkage," in Proceedings of the COMSOL Conference, Milan, Italy, 2012.

[20] W. J. Green, R. L. Carrasquillo, and B. F. McCullough, "Coarse aggregate for PCC-pilot study evaluation," Research Report 422-1, Center for Transportation Research, The University of Texas at Austin, September 1987.

[21] F. Zhu and K. Li, "Modeling heat and moisture transfer within porous textiles under high temperature gradients," Advanced Materials Research, vol. 455-456, pp. 1136-1139, 2012.

[22] Z. H. Wang, Y. M. Zhu, S. Yu, and F. Wang, "Simulation and analysis of temperature field and stress field of sluice pier concrete during construction," Journal of Tianjin University Science and Technology, vol. 41, no. 4, pp. 476-481, 2008. 


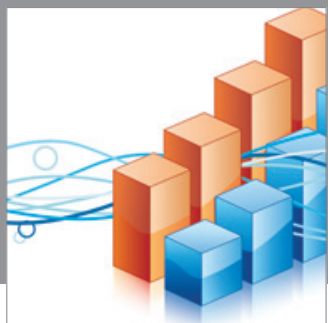

Advances in

Operations Research

mansans

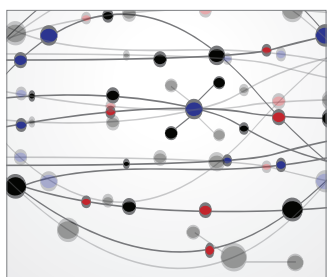

The Scientific World Journal
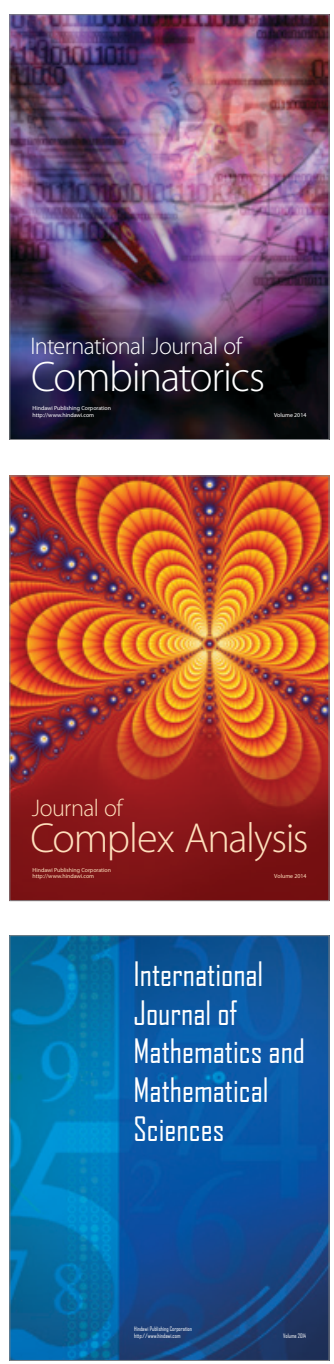
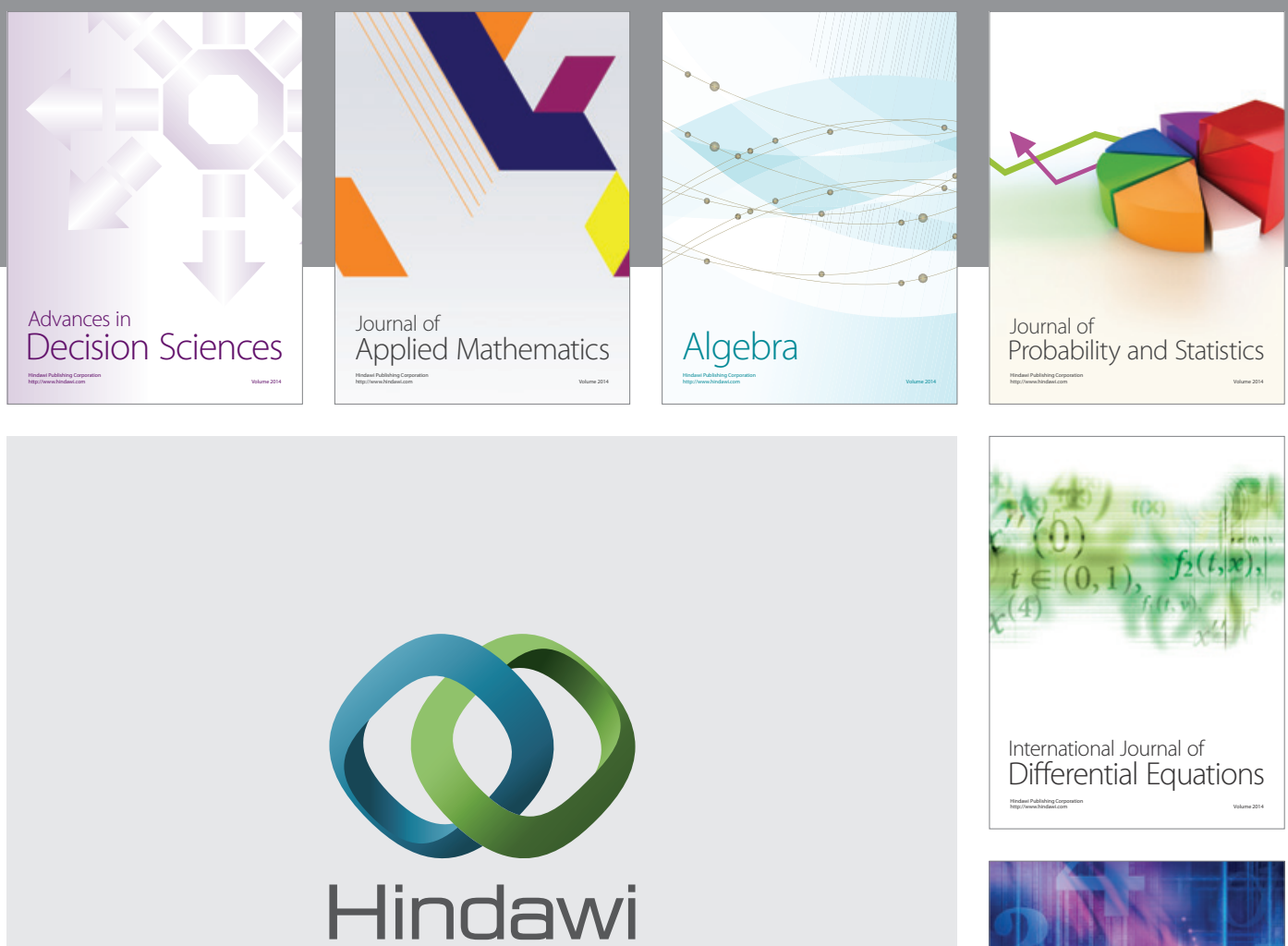

Submit your manuscripts at http://www.hindawi.com
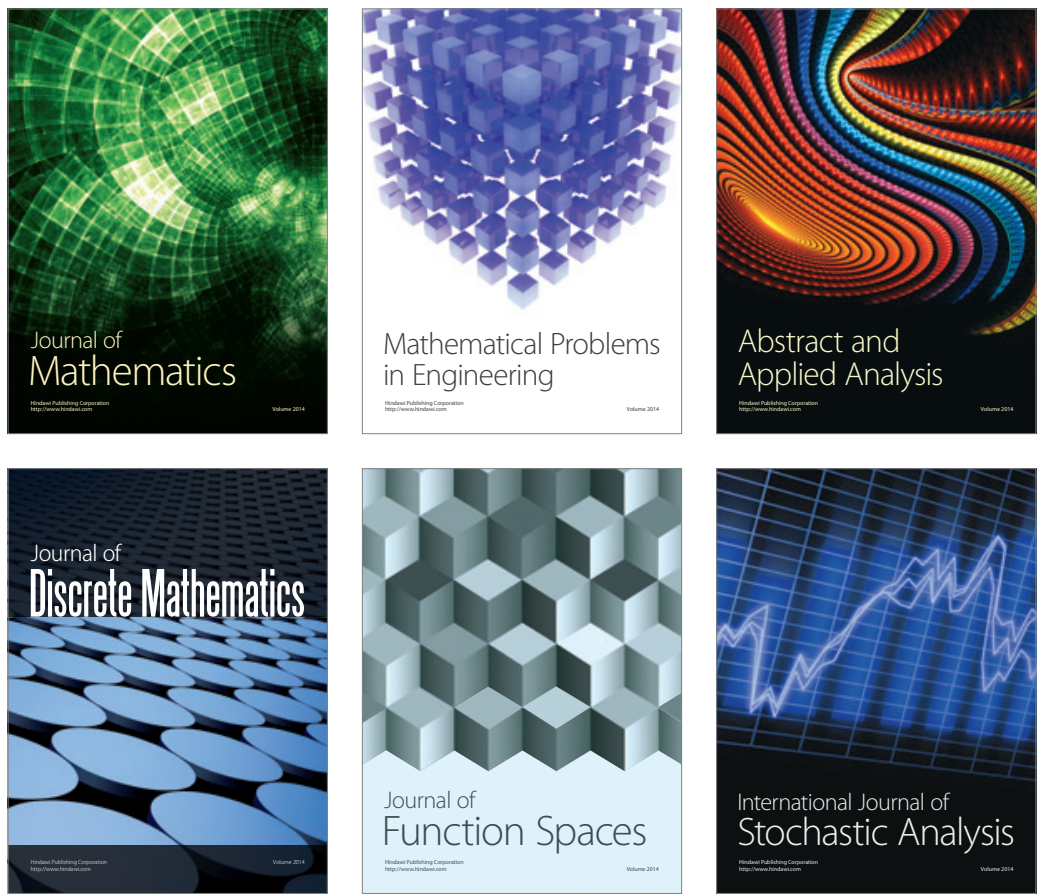

Journal of

Function Spaces

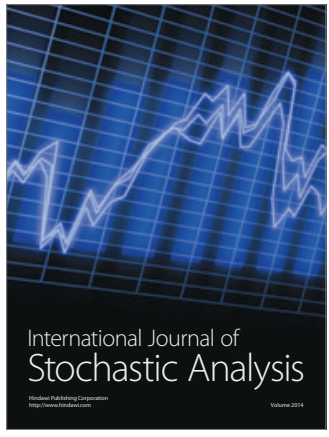

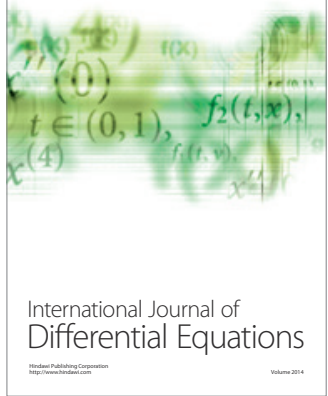
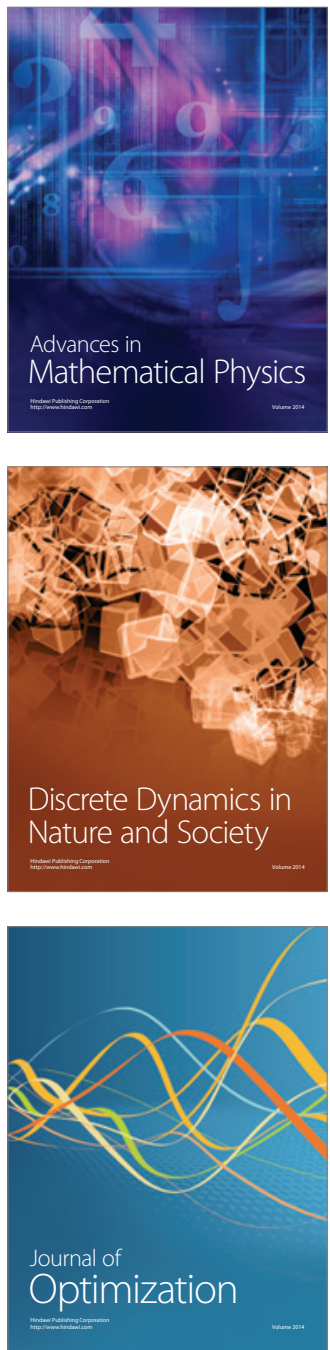